\title{
APPLICATION OF RESPONSE SURFACE METHOD TO COPPER CEMENTATION BY METALLIC ALUMINUM PARTICLES
}

\author{
Nizamettin Demirkıran ${ }^{1}{ }^{凶}$, G. Deniz Turhan $\ddot{z}_{z d e m i r}{ }^{1}, M_{\text {erve Dardağan }}{ }^{1}$
}

https://doi.org/10.23939/chcht14.04.590

\begin{abstract}
In the present study, the interactive effects of the process variables containing copper concentration, temperature, and time on the efficiency of copper cementation by metallic aluminum particles were examined by using response surface methodology (RSM). It was observed that the efficiency of cementation increased with an increase in the initial concentration of copper, temperature and time. The multiple regression analysis to the experimental data was applied to see the interactive effects of process variables. The second-order polynomial equation was obtained. The optimal values were found to be $0.075 \mathrm{~mol} / 1,303 \mathrm{~K}$, and $90 \mathrm{~min}$ to maximize the amount of the deposited copper.
\end{abstract}

Keywords: copper, cementation, optimization, response surface methodology.

\section{Introduction}

In hydrometallurgical processing of ores, the cementation method has been applied for a long time to obtain the desired metal species or to eliminate the unwanted metals from leach solutions. This method that is based on electrochemical fundamental involves reduction of metal ions by a galvanic interaction between noble metal ions and a more electropositive sacrificial metal in an aqueous solution without an external source of electrical current. The more active metal dissolves anodically while noble metal ions deposit cathodically. Thus, the electrons required for the reduction of noble metal ions are provided by a charge exchange or metal displacement reactions [1-6].

A cementation or metal displacement reaction can be described by Eq. (1):

$$
n \mathrm{~A}^{a^{+}}+m \mathrm{~B}^{o} \rightarrow n \mathrm{~A}^{o}+m \mathrm{~B}^{b+}
$$

where $n, m, \mathrm{~A}, \mathrm{~B}, a+$, and $b+$ represent the stoichiometric coefficients, noble and reductant metals, and valences of noble and reductant metals, respectively.

\footnotetext{
${ }^{1}$ Department of Chemical Engineering, Faculty of Engineering, İnönü University, Malatya, 44280, Turkey

$\triangle$ nizamettin.demirkiran@inonu.edu.tr

(c) Demirkıran N., Özdemir D, Dardağan M., 2020
}

Cementation method can be applied as a separation and purification or a recovery process. For example, before the electrowinning of zinc from the solution obtained by leaching of roasted zinc ore, the impurities such as cadmium, cobalt, copper and nickel in the solution can be removed by zinc cementation. Also, in hydrometallurgical processing of oxidized copper ores, copper can be recovered from a leach solution by using zinc, aluminum or iron [7,8]. Although this technique is not a new technology, it is frequently applied to the solutions obtained via different industrial processes and containing various metal ions because of its simplicity and ease of control.

Copper is one of the most prevalent and valuable metals used in industry because of its electrical, thermal, optical and catalytic properties. Copper is mainly used in the electrical and electronics industries due to its high electrical conductivity. Copper cementation is usually performed to remove copper ions from the electrowinning or electroplating solutions or to recover copper from leach solutions $[4,9]$.

The studies on copper cementation in the literature mostly focus on cementation kinetics. In the kinetic studies, the parameters affecting metal displacement reaction are investigated within a certain value range. Only one experimental parameter is changed while the other parameters are kept constant during the reaction. In this manner, the effects of all experimental parameters on cementation reaction are singly studied. Thus, it is required to perform numerous experiments, and the interactions among parameters cannot be observed. The efficiency of cementation reaction, deposit formation, and progression of the reaction are affected by the process variables and their values. To make the process more effective by determining the optimal operating conditions, it is necessary to know the mutual interaction among these variables. Statistical experimental design techniques can be applied to improve the cementation process by optimizing values of process variables. In a statistical experimental design, the experimental parameters can be simultaneously varied. Thus, a lot of information about the process can be obtained with a minimum number of 
trials. For this reason, the experimental design is a useful tool to see the interactions between two or more variables by reducing a number of trials $[2,4,10]$.

Response surface methodology (RSM) is a combination of statistical and mathematical methods that are useful for designing experiments, modelling, analyzing the effects of variables, and optimization of engineering problems. In this technique, the main objective is to optimize the response surfaces influenced by various process parameters. This methodology was widely adopted in the industries, such as drug and food industry, chemical and biological processes for the purpose of either producing high quality products or operating the process in a more economical manner and ensuring the process in a more stable and reliable way [ 10 , 11-14].

One of the most important events in cementation reactions is whether deposit formed on the reductant metal surface is coherent. A coherent deposit formed on a metal surface affects the reaction rate and controlling-step of the reaction. Among the parameters mentioned above, especially the concentration and reaction temperature are more effective parameters because a porous deposit layer can form generally at their high values. The present study relates to the optimization of parameters affected the copper cementation by using metallic aluminum. The interactive effects of process variables including the initial concentration of copper, reaction temperature, and reaction time on cementation efficiency were determined by keeping the stirring speed and initial $\mathrm{pH}$ of solution at constant values, and response surface methodology was employed to optimize these process variables.

\section{Experimental}

Cementation tests were carried out in 11 cylindrical glass reactor equipped with a mechanical stirrer, and a reaction temperature control unit. The test solutions containing copper ions were prepared by using $\mathrm{CuSO}_{4} \cdot 5 \mathrm{H}_{2} \mathrm{O}$. The initial $\mathrm{pH}$ of solutions was adjusted to 2 by adding diluted $\mathrm{H}_{2} \mathrm{SO}_{4}$ solutions. Spherical aluminum particles (1.5-2.0 $\mathrm{mm}$ of average diameter) used in the experiments were prepared by using the aluminum foil. After $250 \mathrm{ml}$ of solution was put into the glass reactor and brought to the desired reaction temperature, 1.5 times of stoichiometrically required metallic aluminum particles were added into the reactor. The reactor content was stirred at stirring speed of $500 \mathrm{rpm}$ during experiments. At the end of the reaction time, the amounts of copper ions in the solution were determined complexometrically using titriplex(III) solution as a titrant and murexide as an indicator. The amount of deposited copper was calculated in percentage terms as given in Eq. (2):

$$
\% \text { precipitated copper }=\frac{C_{0}-C_{t}}{C_{0}} \cdot 100
$$

where $C_{0}$ and $C_{t}$ are the initial and final concentrations of copper in the solution, respectively, $\mathrm{mol} / \mathrm{l}$.

The level of independent variables and their experimental ranges are given in Table 1.

Table 1

The experimental ranges and levels of independent variables

\begin{tabular}{|c|c|c|c|c|}
\hline \multirow{2}{*}{ Independent variables } & \multirow{2}{*}{ Sign } & -1 & 0 & \multicolumn{2}{|c|}{ Level } \\
\cline { 3 - 5 } & & 0.005 & 0.04 & 0.075 \\
\hline Concentration, $\mathrm{mol} / \mathrm{l}$ & $X_{1}$ & 30 & 50 & 70 \\
\hline Temperature, ${ }^{\circ} \mathrm{C}$ & $X_{2}$ & 15 & 50 & 90 \\
\hline Time, $\min$ & $X_{3}$ & &
\end{tabular}

\section{Results and Discussion}

Cementation reaction between the solution containing copper ions and metallic aluminum particles occurs according to the following reaction:

$$
3 \mathrm{Cu}^{2+}+2 \mathrm{Al}^{0} \rightarrow 3 \mathrm{Cu}^{0}+2 \mathrm{Al}^{3+}
$$

Due to the difference between the electrode potentials of the two metals, copper ions are easily reduced to its metallic state on the aluminum surface while aluminum is oxidized to its ionic form. The standard reduction potentials of copper and aluminum are 0.34 and $-1.67 \mathrm{~V}$, respectively. The half-cell reactions can be written as follows:

$$
\mathrm{Cu}^{2+}+2 \mathrm{e}^{-} \rightarrow \mathrm{Cu}^{0}\left(E^{0}=0.34 \mathrm{~V}\right)
$$

$$
\mathrm{Al}^{0} \rightarrow \mathrm{Al}^{3+}+3 \mathrm{e}^{-} \quad\left(E^{0}=1.67 \mathrm{~V}\right)
$$

$\Delta E^{0}$ of the total reaction is positive $(+2.01 \mathrm{~V})$, and the standard Gibbs free energy $\Delta G^{0}$ is to be negative. Therefore, a spontaneous heterogeneous reaction on the metallic aluminum surface takes place through the galvanic cell.

In the experimental design, RSM is used to determine the effects of independent variables on the response or dependent variable and to obtain the optimal response. Central composite design (CCD) is one of the most commonly utilized methods of RSM. It can be used to optimize the levels of factors and to obtain a second order polynomial model for predicting the response [10]. In the present work, $\mathrm{CCD}$ was applied to investigate the 
performance of copper cementation and to determine the optimal experimental conditions.

CCD involves a two level factorial design $(+1,-1)$ superimposed by the center points (coded 0) and star points. These values are shown in Table 1 . Since three different independent variables are selected, a $2^{3}$ full factorial central composite design with 6 axial points and 4 repetitions at the center point were used for RSM. The expression of $2^{n}+2 n+4$ gives the total number of experiments as 18 for three independent variables shown in Table 1.The experimental planning proposed by CCD and the responses obtained from these experiments are given in Table 2.

A second-order polynomial modelgiven in Eq. (6) was obtained by applying multiple regression analysis to the experimental data. Eq. (6) shows the empirical relationship between the deposited copper (response) and the independent variables.

$$
\begin{aligned}
& Y=81.19+21.71 X_{1}+0.42 X_{2}+7.50 X_{3}-3.38 X_{1} X_{2}+ \\
& +0.59 X_{1} X_{3}+1.84 X_{2} X_{3}-4.61 X_{1}^{2}-2.11 X_{2}^{2}-3.12 X_{3}^{2}
\end{aligned}
$$

The quadratic model in Eq. (6) involves one constant term, three linear terms, three quadratic terms, and three two-factor interactions.

Analysis of variance (ANOVA) and $F$-test were conducted to test the statistical significance and adequacy of the model in Eq. (6) using the Design Expert Software. The results obtained are shown in Table 3 . The probability values ( $P$-values) seen in Table 3 can be used as a tool to check the significance of each variable and their interactions.

Table 2

\begin{tabular}{|c|c|c|c|c|c|}
\hline \multirow{2}{*}{ Exp. run } & \multirow{2}{*}{$X_{1}, \mathrm{~mol} / 1$} & \multirow{2}{*}{$X_{2},{ }^{\circ} \mathrm{C}$} & \multirow{2}{*}{$X_{3}, \min$} & \multicolumn{2}{|c|}{$Y, \%$} \\
\hline & & & & Experimental & Predicted \\
\hline 1 & 0.005 & 30 & 90 & 45 & 48 \\
\hline 2 & 0.005 & 70 & 90 & 50 & 52 \\
\hline 3 & 0.075 & 70 & 90 & 92 & 90 \\
\hline 4 & 0.040 & 70 & 50 & 81 & 80 \\
\hline 5 & 0.040 & 30 & 50 & 76 & 79 \\
\hline 6 & 0.040 & 50 & 50 & 80 & 81 \\
\hline 7 & 0.040 & 50 & 50 & 81 & 81 \\
\hline 8 & 0.040 & 50 & 90 & 84 & 86 \\
\hline 9 & 0.075 & 50 & 50 & 90 & 88 \\
\hline 10 & 0.040 & 50 & 50 & 82 & 81 \\
\hline 11 & 0.075 & 70 & 15 & 66 & 70 \\
\hline 12 & 0.040 & 50 & 50 & 80 & 81 \\
\hline 13 & 0.005 & 50 & 50 & 42 & 45 \\
\hline 14 & 0.040 & 50 & 15 & 72 & 71 \\
\hline 15 & 0.005 & 70 & 15 & 37 & 28 \\
\hline 16 & 0.005 & 30 & 15 & 29 & 31 \\
\hline 17 & 0.075 & 30 & 90 & 90 & 86 \\
\hline 18 & 0.075 & 30 & 15 & 82 & 80 \\
\hline
\end{tabular}

The experimental design matrix of CCD and corresponding results

A value of $P r o b>F$ less than 0.050 indicates that the related independent variable in the model has a significant influence on the process. The model $F$-value of 67.29 for this cementation process specifies that the model was significant $(P$-value $<0.05)$. At the same time, it is observed from Table 3 that $P$-values for the terms of $X_{1}$, $X_{3}, X_{1} X_{2}$, and $X_{1}^{2}$ are less than 0.05 . Thus, it can be said that the terms of $X_{1}, X_{3}, X_{1} X_{2}$, and $X_{1}^{2}$ in Eq. (6) are statistically meaningful terms. The statistical model $\left(R^{2}=\right.$ $=0.987$ ) in Eq. (6) allows the prediction of concentration, reaction temperature, and reaction time with a good accuracy. To test the agreement between the experimental and predicted responses from the empirical model, a graph of the predicted responses versus the experimental responses was plotted in Fig. 1. It can be observed from this figure that the agreement between the experimental and calculated responses is very good.

Three dimensional response surfaces obtained from the quadratic model for copper cementation yield were drawn using the Design Expert Software. Figs. 2-4 demonstrate the relationships between the responses and experimental levels for each variable. These plots can be used to see the effect of any of the two variables, while the other variable is kept at its center level. On the response surfaces, the clear peaks illustrate that the optimal conditions are exactly inside the design boundary and the optimum values drawn from these figures are in close agreement with those obtained by optimizing the regression equation. An analysis of Figs. 2-4 shows that the cementation yield increases with increasing all three parameters. 
Table 3

ANOVA result of the quadratic model

\begin{tabular}{|c|c|c|c|c|c|c|}
\hline Source & Coefficients & $\begin{array}{c}\text { Sum of } \\
\text { squares (SS) }\end{array}$ & $\begin{array}{c}\text { Degree of } \\
\text { freedom (DF) }\end{array}$ & $\begin{array}{c}\text { Mean square } \\
\text { (MS) }\end{array}$ & F-Value & Prob. $>$ F \\
\hline$A_{0}$ & 81.19 & & & & & \\
\hline$X_{1}$ & 21.71 & 4711.25 & 1 & 4711.25 & 422.34 & $<0.0001$ \\
\hline$X_{2}$ & 0.42 & 1.80 & 1 & 1.80 & 0.16 & 0.6983 \\
\hline$X_{3}$ & 7.50 & 562.50 & 1 & 562.50 & 50.42 & 0.0001 \\
\hline$X_{1} X_{2}$ & -3.38 & 91.13 & 1 & 91.13 & 8.17 & 0.0212 \\
\hline$X_{1} X_{3}$ & 0.59 & 2.75 & 1 & 2.75 & 0.25 & 0.6328 \\
\hline$X_{2} X_{3}$ & 1.84 & 27.06 & 1 & 27.06 & 2.43 & 0.1580 \\
\hline$X_{1}^{2}$ & -14.61 & 578.16 & 1 & 578.16 & 51.83 & 0.0001 \\
\hline$X_{2}^{2}$ & -2.11 & 12.03 & 1 & 12.03 & 1.08 & 0.3294 \\
\hline$X_{3}^{2}$ & -3.12 & 26.13 & 1 & 26.13 & 2.34 & 0.1644 \\
\hline Model & & 6755.70 & 9 & 750.63 & 67.29 & 0.0001 \\
\hline Residual & & 89.24 & 8 & 11.16 & & 18.87 \\
\hline Lack of fit & & 86.49 & 5 & 17.30 & & \\
\hline Pure error & & 6844.94 & 17 & & & \\
\hline Total & & & 3 & & \\
\hline
\end{tabular}

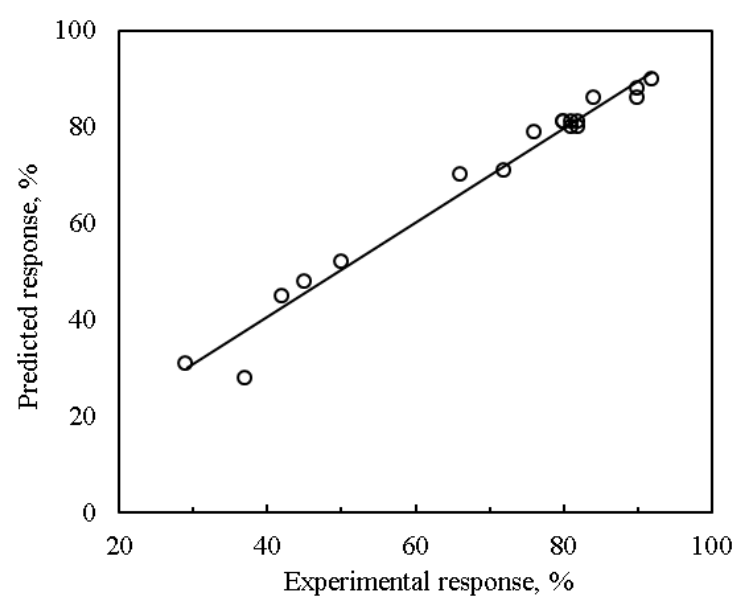

Fig. 1. The graph of the predicted responses versus the experimental responses

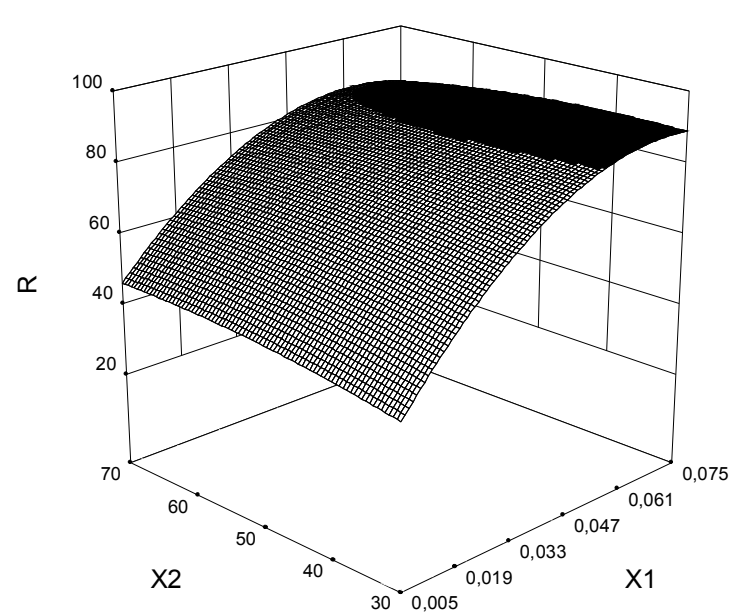

Fig. 2. The interactive effect of concentration nd temperature on cementation yield

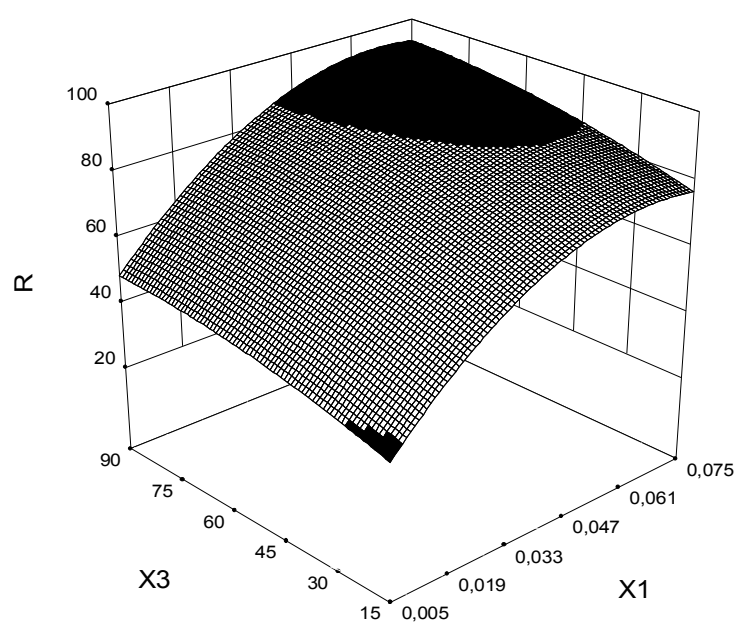

Fig. 3. The interactive effect of concentration and time on cementation yield 


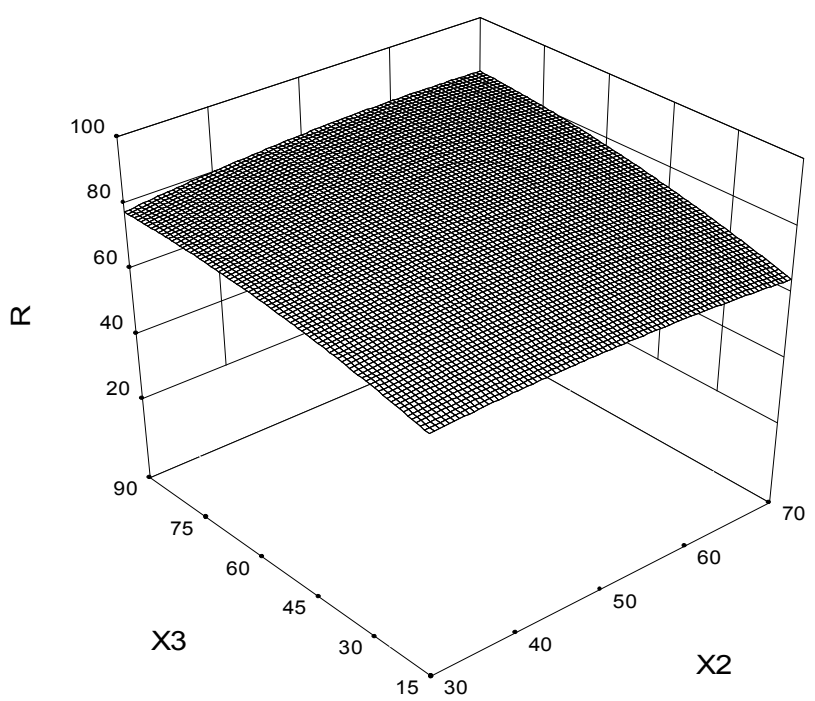

The interactive effect of copper concentration and reaction temperature on the deposited copper is shown in Fig. 2. It can be seen from this figure that the reaction yield increases with an increasing initial concentration and temperature. Fig. 3 illustrates the interactive relationship between the concentration and reaction time on copper cementation. This figure indicates that the deposited copper increases with an increase concentration and reaction time. Fig. 4 shows the interactive effect between the reaction temperature and reaction time on copper cementation. It is understood that the cementation process is affected positively from an increase in the reaction temperature and reaction time. The effects of these parameters on the reaction yield can be commented as below.

The rate of cementation reactions is proportional to the concentration of metal ions in the solution and the sacrificing metal surface area. When the amount of aluminum is comparatively increased with increasing

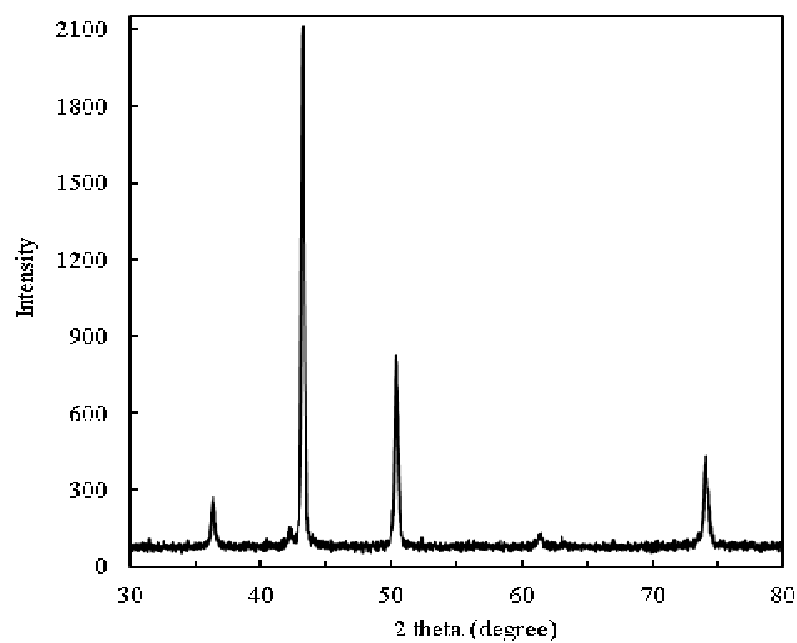

Fig. 5. XRD pattern of copper powder obtained by cementation at optimal conditions
Fig. 4. The interactive effect of temperature and time on cementation yield initial copper ion concentration during experiments, the effective surface area becomes higher; as a result, the amount of precipitated copper increases. In addition, it is known that the reaction rate increases with increasing temperature. A porous copper layer on the surface of aluminum metal can form at high concentrations of copper ions and reaction temperature. In this situation, copper ions can easily diffuse towards the reducing metal surface through the porous deposit layer with the help of agitation. The reaction time affects the cementation yield in a positive direction. The yield increases with an increase the reaction time. Thus, the cementation yield increases with increasing values of these parameters.

The optimal experimental conditions were determined by using the optimization module in DesignExpert software. Different solution points were obtained as a result of optimization. The optimal cementation conditions obtained and the responses are given in Table 4.

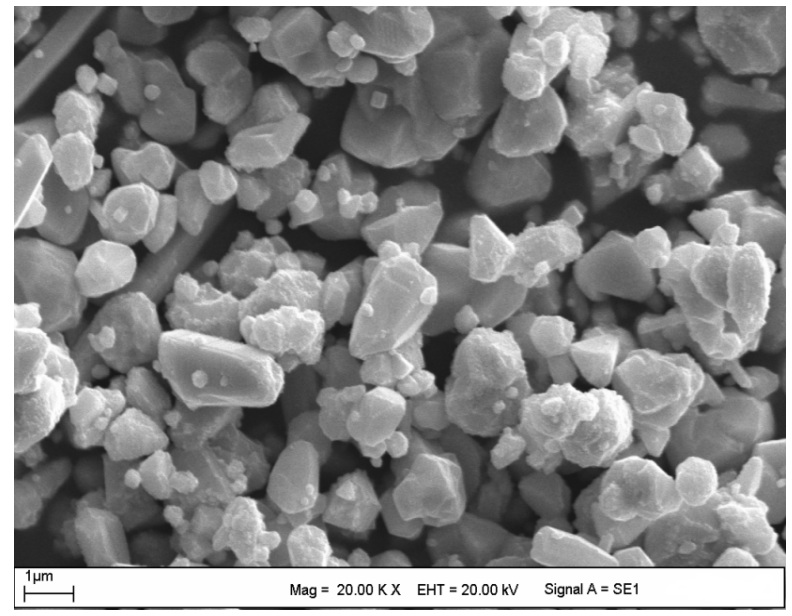

Fig. 6. SEM image of precipitated copper 
The optimum solution points obtained according to CCD

\begin{tabular}{|c|c|c|c|c|}
\hline Solution number & $X_{1}$ & $X_{2}$ & $X_{3}$ & Estimated \% deposited $\mathrm{Cu}$ \\
\hline 1 & 0.075 & 70 & 90 & 90 \\
\hline 2 & 0.075 & 30 & 90 & 92 \\
\hline 3 & 0.075 & 50 & 90 & 93 \\
\hline
\end{tabular}

To maximize the amount of the deposited copper, the optimal values can be selected to be $0.075 \mathrm{~mol} / \mathrm{l}$, $1073 \mathrm{~K}$, and $90 \mathrm{~min}$. An experiment was made by using optimal values, and it was determined that $90 \%$ of copper in the solution was deposited. It can be said that this experimental value is in good agreement with the estimated value in Table 4. An XRD pattern of copper powder obtained by the cementation method at optimal conditions is given in Fig. 5. The major diffraction peaks in Fig. 5 shows a metallic copper. Fig. 6 shows a SEM image of the precipitated copper at optimal conditions $(0.075 \mathrm{~mol} / \mathrm{l}, 1073 \mathrm{~K}, 90 \mathrm{~min})$. It can be observed from this figure that metallic copper obtained are nonagglomerated polyhedral structure.

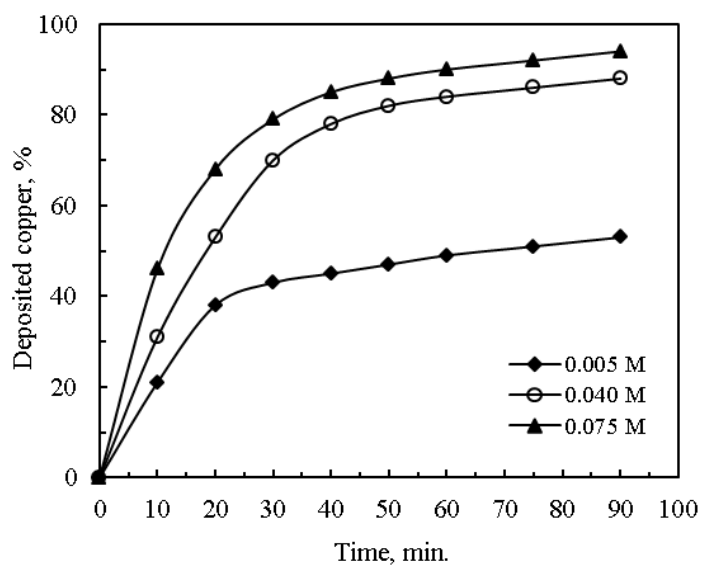

Fig. 7. The effect of copper concentration on the cementation rate at the optimal temperature

To see the progress of the cementation process with time, some experiments were carried out. In these experiments, the reaction temperature was kept constant at the optimal temperature while the initial concentration of copper was changed in the range of $0.005-0.075 \mathrm{~mol} / \mathrm{l}$. During these tests, the initial $\mathrm{pH}$ of aqueous solutions and stirring speed were taken constant at 2 and $500 \mathrm{rpm}$, respectively. The experimental results obtained are given in Fig. 7. As can be seen from Fig. 7, the cementation rate of copper ions increased with increasing the initial copper concentration. Thus, it is understood that the initial copper concentration has an important effect on the cementation rate of copper. Since the cementation reaction between copper ions and aluminum particles occurs at the aluminum surface, the precipitated copper accumulates on the metal surface and generates a resistance to the diffusion of copper ions towards a sacrificing metal surface. Therefore, the cementation rate decreases progressively with time.

\section{Conclusions}

In this study, the interactive effects of process variables including the initial concentration of copper, reaction temperature, and reaction time on the efficiency of copper cementation by using a metallic aluminum were investigated. Response surface methodology was employed to optimize these process variables. The findings obtained demonstrated that the cementation process was affected positively from an increase in the initial concentration of copper, reaction temperature and reaction time. The multiple regression analysis to the experimental data was applied to see the interactive effects of process variables. A representative statistical model showing the relationship between the deposited copper and independent variables was attained. It was observed that the empirical model represented finely the agreement between the experimental and predicted values. The optimal experimental conditions were also determined, and different solution points were observed. The optimal values were selected to be $0.075 \mathrm{~mol} / 1,1073 \mathrm{~K}$, and $90 \mathrm{~min}$ to maximize the amount of the deposited copper. At the end of an experiment performed by using the optimal values, it was found that $90 \%$ of copper was deposited.

\section{References}

[1] Sedzimir J.: Hydrometallurgy, 2002, 64, 161. https://doi.org/10.1016/S0304-386X(02)00033-6

[2] Djoudi W., Issani-Benissad F., Bourouina-Bacha S.: Chem. Eng. J., 2007, 133, 1. https://doi.org/10.1016/j.cej.2007.01.033

[3] Noubactep C.: J. Hazard. Mater., 2010, 181, 1170. https://doi.org/10.1016/j.jhazmat.2010.05.085

[4] Nazim M., Pal P., Al Shoaibi A., Elkamel A.: Chem. Eng. Technol., 2012, 35, 1744. https://doi.org/10.1002/ceat.201100492

[5] Demirkiran N.: Sep. Sci. Technol., 2013, 48, 827. https://doi.org/10.1080/01496395.2012.710702

[6] El-Shazly A., Nassr A., Mubarak A., Zaatout A.: Desalin. WaterTreat., 2016, 57, 22835.

https://doi.org/10.1080/19443994.2015.1133872

[7] Ekmekyapar A., Tanaydın M., Demirkiran N.: Physicochem. Probl. Miner. Process., 2012, 48, 355. https://doi.org/10.5277/ppmp120203 
[8] Gouvea L., Morais C.: Miner.Eng., 2007, 20, 956.

https://doi.org/10.1016/j.mineng.2007.04.016

[9] Demirkiran N.: Ind. Eng. Chem. Res., 2013, 52, 8157. https://doi.org/10.1021/ie400438b

[10] Yahiaoui I., Aissani-Benissad F., Ait-Amar H.: Can. J. Chem. Eng., 2010, 88, 1099. https://doi.org/10.1002/cjce.20348

[11] Sudamalla P., Saravanan P., Matheswaran M.: Sustain. Environ. Res., 2012, 22, 1.

[12] Ottoni C., Cuervo-Fernández R., Piccoli R. et al.: Braz. J. Chem. Eng., 2012, 29, 49. https://doi.org/10.1590/S010466322012000100006

[13] Shalchian H., Rafsancani-Abbasi A., Vahdati-Khakl J., Babakhani A.: Metall. Mater. Trans. B, 2015, 46B, 38. https://doi.org/10.1007/s11663-014-0216-7

[14] Salehi S., Noaparast M., Shafaei S.: Physicochem. Probl. Miner. Process., 2016, 52, 1023.

https://doi.org/10.5277/ppmp160239

Received: February 15, 2019 / Revised: March 11, 2019 / Accepted: June 25, 2019

\section{ЗАСТОСУВАННЯ МЕТОДУ КРУТОГО СХОДЖЕННЯ ДЛЯ ЦЕМЕНТАЦІї МІДІ МЕТАЛЕВИМИ ЧАСТИНКАМИ АЛЮМІНІЮ}

\begin{abstract}
Анотація. 3а допомогою методу крутого сходження досліджено взаємний вплив концентрайї міді, температури та тривалості процесу на ефективність цементації міді металевими частинками алюмінію. Встановлено, що ефективність цементації збільшується зі збільшенням початковоі концентрації міді, температури $i$ часу. Аналіз множинної регресії стосовно експериментальних даних показав взаємний вплив змінних процесу. Отримано поліноміальне рівняння другого порядку. Визначено оптимальні параметри прочесу: кониеетрачія 0,075 моль/л, температура $1073 \mathrm{~K}$ i час 90 хв., за яких отримують максимальну кількість осадженої міді.
\end{abstract}

Ключові слова: мідь, цүементація, оптимізація, метод крутого сходження. 